\title{
Factors Affecting the Use of Price Risk Management Tools by Large Commercial Maize Producers in South Africa
}

\section{A Brown, G F Ortmann and M A G Darroch}

School of Agricultural Sciences \& Agribusiness, University of Natal, Pietermaritzburg

\section{ABSTRACT}

Ordinary Least Squares regression was used to examine what characteristics affect the use of maize price risk management tools by a sample of large commercial South African maize producers in 1998. The use of maize storage facilities, off-farm employment, formal crop insurance, length of formal education of operators and the proportion of farm turnover from maize, all positively influence producers' use of these tools. Crop insurance thus appeared to be a complementary method of risk management. In contrast to previous United States studies, operators' self-rated score of marketing management ability was negatively related to the use of price risk management tools. Maize marketing seminars and other sources of information on managing price risk would reduce adoption costs and encourage broader producer participation.

JEL Q 12

\section{INTRODUCTION}

Maize was the second largest contributor (R4.4 billion), after poultry, to South Africa's gross value of agricultural production (R42.4 billion) in 1997/98. South African maize production is concentrated in the North-West Province, Free State and Mpumalanga which, respectively, accounted for 32, 33 and 21 percent of maize production in the five years since 1993/94 (Directorate: Statistical Information, 1999).

Maize marketing in South Africa was highly regulated from the 1930s until the mid 1990 s, with maize being sold through a single-channel system administered by the Maize Board, which also set producer prices. The Maize Board was eventually disbanded in April 1997 after the passing of the Marketing of Agricultural Products Act of 1996 (Mielies/Maize, 1997). The deregulation of maize marketing has placed the responsibility for the marketing of this 
important agricultural commodity in the hands of producers, and will probably expose them to greater price risk.

Several new maize marketing altematives have consequently evolved in recent years and the channels which farmers employ to market their crop are changing. Flexible, sequential marketing strategies allow farmers to spread sales over time and thereby manage price risk (Musser et al., 1996:66). Three main markets have emerged for maize in South Africa: the cash (spot) market, forward contracting and the derivatives market. Producers may now sell maize to whoever they please for whatever price they can get in the cash (spot) market, or forward contract their crop to assure prices prior to harvest (Van der Merwe, 1998). The derivatives market involves the trading of futures and options contracts, usually through the South African Futures Exchange (SAFEX). Physical delivery of maize is generally avoided, but acceptable price levels are "fixed-in" prior to delivery (futures contracts), or minimum prices are guaranteed, with potential left for gains from positive price movements (options contracts) (Frank, 1992).

Since many price risk management tools may be effectively substituted for each other and farmers are expected to use a portfolio of price risk management tools, it would be simplistic to consider the use of any single tool in isolation. Previous studies in the United States (US) have considered the adoption of single marketing alternatives (Goodwin \& Schroeder, 1994; Makus et al., 1990; Shapiro \& Brorsen, 1988), such as futures hedging, but no studies were found which considered farmers' use of a full range of substitutable price risk management tools. This study should, therefore, make a useful contribution to the scarce South African literature on the topic of price risk management in maize marketing.

The objective of this study is to examine the recent marketing behaviour of South African commercial maize producers, and estimate by regression analysis what business and personal characteristics affect their use of price risk management tools. The data presented were elicited in a postal survey of a sample of National Maize Producers' Organisation (NAMPO) members in the three major maize growing regions of South Africa, namely the North-West Province, Mpumalanga and the Free State in 1998. The sample cannot be considered representative of all South African maize farmers and is biased towards larger specialised maize producers. The questionnaire used was developed to measure respondents' business, personal and marketing characteristics. The paper first describes the postal survey and characteristics of the respondents. It then explains how an index of the use of price risk management tools was developed for each sample farmer. The following section describes the rationale for selecting relevant variables which may 
explain variation in the index, and presents regression model results. The concluding section discusses the information and management implications of the results.

\section{THE SURVEY AND CHARACTERISTICS OF RESPONDENTS}

\section{The postal survey}

A postal survey was conducted in 1998 amongst a sample of maize farmers in the three study regions (The North-West Province, Free State and Mpumalanga), based on the NAMPO mailing list of its over 7000 members nationwide. This membership list is divided into magisterial districts, and members are assigned to magisterial districts according to their postal addresses. Average annual maize production has exceeded 100000 tons in each of the top 24 magisterial districts. These districts accounted for an average of 61 percent of total South African commercial maize production over the previous ten years. An index score was created to quantify average tonnage of maize produced per NAMPO member in each magisterial district. The ten magisterial districts with the highest indices were drawn from this list and farmers were sampled randomly, according to the districts' average contribution to maize production over the previous ten years. The resulting sample comprised some 301 farmers from the North-West Province, 272 from Mpumalanga and 227 from the Free State.

Of the 800 questionnaires sent out in June 1998, a total of 107 were retumed, yielding an overall response rate of 13.4 percent. Response rates were similar between the regions, ranging from 12.1 percent in Mpumalanga to 15.9 percent in the Free State. Some 26 returned questionnaires were initially unusable because important marketing responses were incomplete. The relevant questions in 20 of these incomplete questionnaires were mailed back to respondents who had given their addresses, in an effort to increase the number of useable responses. Ten of these were returned, leaving the total number of unusable responses at 16. Thus, 91 responses in total were useable for evaluating the maize marketing statistics, giving an 11.4 percent useable response rate, although a 13.4 percent useable response rate (all 107 respondents) was recorded for certain business and farmer characteristics.

Survey data, such as these, which rely on voluntary provision of information are subject to many sources of error. Error may arise due to failure to properly recall events, deliberate distortion of the facts or refusal to participate in the study (Norušis, 1993: 167). In addition, if certain respondents refuse to participate or answer certain questions, further bias will arise. Since the focus of 
this study is on the use of maize price risk management alternatives, and the sample is drawn from the main maize-producing regions of South Africa, the sample is probably biased towards large, specialist maize producers.

\section{General characteristics of sample respondents}

Respondents had an average of 24 years farming experience, 14 years formal education, and a mean age of 47 years. Sample farmers also cultivated an average of 918 ha of maize annually, whilst average annual turnover per farm was R2 862000 , of which 68 percent was derived from maize. The mean value of respondents' assets was R5.6 million, whilst debt averaged R1.5 million. Respondents' debt: asset ratios averaged 0.30 , and ranged from 0 to 0.89 with a mode of 0.25 . Seventy-two percent of respondents reported owning a personal computer for use in the farm business, and of these, 38 percent had Internet access. The Internet was most commonly used for personal e-mail correspondence and access to maize price and management information. Roughly 57 percent of sample farmers considered South African maize marketing to be free and fair, while 43 percent disagreed with this statement. Respondents rated maize yield variability as the most important source of risk they faced. Maize price variability was rated only the joint fourth most important source of risk along with changes in labour legislation and interest rate variability, after exchange rate variability and changes in input costs.

Respondents spent an average of 3.2 hours per week reviewing marketing information. Weekly agricultural magazines (e.g. Farmer's Weekly) were rated the most important sources of maize price information, followed by subscription-based information providers (e.g. Agrimark Trends) and SAFEX. When producers were asked to identify their needs for additional information and services to better manage their maize marketing, the most commonly requested services were for information on price and production trends in international markets. Producers generally rated their skills in marketing management lowest compared to production, financial and general management. A trend of decreasing levels of understanding of forward pricing tools was observed among respondents, from the more familiar concept of forward contracting to the more complex concept of options trading.

\section{AN INDEX OF PRICE RISK MANAGEMENT}

Few observations of futures hedging were recorded (nine percent of cases), whilst only 17 percent of respondents utilised cash (spot) marketing exclusively, implying that the remainder used a portfolio of marketing altematives. Previous studies have focused purely on the forward-pricing aspects of price risk 
management and ignored farmers' use of flexible and sequential marketing strategies. Due to the low number of observations of both hedging and exclusive cash (spot) marketing activities and a wish to measure other aspects of price risk management behaviour, a continuous index of price risk management was composed. This contrasts with previous US studies where discrete adoption of derivatives, and proportion of crops hedged (Shapiro \& Brorsen, 1988; Goodwin \& Schroeder, 1994; Makus et al., 1990) were used as dependent variables. An index was thus created to measure the degree to which respondents used price risk management tools, and serves as the dependent variable in the regression model specified in the next section (Lyne, 1998). The index $\left(I_{i}\right)$ was calculated by formula (1):

$$
I_{i}=\left(\sum_{k=1}^{n s} z \alpha_{i} x z D_{0}\right) x\left(\sum_{i=1}^{n f} z \beta_{i} x z D_{l}\right) x_{z u_{i}}
$$

where: $z \alpha_{i}=$ The standardised proportions of the i-th farmer's crop marketed through cash (spot) market channels, plus a constant term (5).

$z \beta_{i}=$ The standardised proportions of the $\mathrm{i}$-th farmer's crop protected by forward, futures and options contracting mechanisms, plus a constant term (5).

$\mathrm{ns}+\mathrm{nf}=\mathrm{n}=$ The total number of cash (spot) (ns) and forward-pricing (nf) marketing channels used by the i-th farmer.

$\mathrm{zD}=$ The standardised value of a dummy variable scoring 0 for cash market and 1 otherwise, plus a constant term (5).

$z_{i}=$ The standardised value of the total number of marketing channels used by the $\mathrm{i}$-th farmer, plus a constant term (5).

The computed values of this index were then standardised so that the final index $\left(\mathrm{J}_{\mathrm{i}}\right)$ was derived as follows by equation $(2)$ :

$$
J_{i}=z I
$$

The variable $J_{i}$ is an index of price risk management for the ith farmer. It takes into account three aspects of price risk management behaviour exhibited by sample farmers: the use of forward pricing mechanisms (using a dummy variable), the number of different marketing channels used, and the relative proportions of the producer's crop passing through these channels. Higher index scores imply greater use of price risk management tools, such as forward 
pricing and sequential marketing. Due to the standardisation procedure, the scale effects of the different units of measurement of the index components on the resultant index are eliminated. The constant added to each standardised variable (5) simply ensures that all values used in the construction of the index are positive. The index accounts for three aspects of price risk management behaviour, without applying subjective weights to the different components.

Computed values of $\mathrm{J}_{\mathrm{i}}$ for the $1998 / 99$ marketing season lie in the range -1.21 to 3.56 and had a mean value of 0.00 . Thirty-two of the 80 respondents recorded index values above the mean and were classified as "higher-level users of price risk management tools", while 48 respondents had index scores below the mean ("lower-level users of price risk management tools").

\section{THE REGRESSION MODEL}

Ordinary Least Squares (OLS) regression was used to examine relationships between relevant explanatory variables and the index of price risk management score (dependent variable). Probit and Tobit models were used by Goodwin and Schroeder (1994), Makus et al. (1990) and Shapiro and Brorsen (1988), who all examined US grain farmers' use of forward pricing, treating it as a technology adoption decision using dummies and proportions of crop hedged as dependent variables. Edelman et al. (1990) used logistic regression to model the discrete $(0 / 1 / 2)$ adoption of cash marketing, forward contract marketing, futures hedging and options hedging by US grain producers. The OLS method is preferred for the analysis of local price risk management tools because the $J_{i}$ index score is continuous.

\section{Variables hypothesised to affect respondents' use of price risk management tools}

Adapting economic theory on technology adoption, and the US studies previously outlined, the following factors are postulated to affect the sample South African maize farmers' adoption and degree of use of price risk management tools:

- Farm size is expected to be positively related to the use of both forward contracting and derivatives. The scale-dependent potential gains of price risk management tools increase, and fixed (information and transaction) costs associated with their use can be spread over a larger volume of output, as farm size increases. The "lumpy" nature of some marketing contracts due to specified unit contract and order volumes, also favours larger producers. The size of the maize enterprise is particularly 
important, and various measures of farm size were considered, including turnover (Rand) and area (hectare) indicators.

- Education is expected to have a positive effect on the adoption of price risk management tools. More educated farmers would probably have lower transaction costs associated with adopting the "new technology" of more complicated marketing tools. It should take less time and effort for more educated individuals to better understand and use such tools. Education was measured by the respondents' number of years of formal education (e.g. 12 years represents matric level, and 15 years a three-year degree or diploma).

- Financially stressed farmers would more likely use price risk management tools due to their being relatively less able to bear risk. Hedging can be a source of liquidity and lenders are expected to favour those who "lock-in" forward prices (Turvey, 1989). Relative indebtedness among respondents was proxied by comparing sample farmers' debt:asset ratios.

- Farming experience is expected to have a negative effect on the adoption of price risk management tools. More experienced farmers, who were used to the previous regulated marketing environment, may be slower to adopt novel marketing techniques such as hedging. Previous studies in the US (Goodwin \& Schroeder, 1994; Shapiro \& Brorsen, 1988) found that experience was negatively related to commercial grain farmers' use of derivatives. The experience variable is likely to be positively correlated to farmers' age and can be used as a proxy for it. Experience was measured as the number of years of employment on a farm since the age of 18.

- Risk aversion should positively influence the use of price risk management tools, ceteris paribus. In reality, all other things are however not equal. Economic theory recognises two forms of risk facing farmers: financial risk incurred due to the fixed, contractual obligations associated with debt financing, and business risk incurred independently of the way the business is financed and caused by factors like price and yield variability (Barry et al., 1995). Forward pricing tools can be used to manage price risk which is an important source of business risk. However, there are many other business and financial risks that comprise the total risk facing the farmer. There are a variety of alternative methods which may substitute for, or complement, forward pricing tools in risk management. Measurement of risk aversion per se is difficult, because farmers' use of alternative risk management measures will affect their exposure to risk and thus their attitude towards it. Consequently, few studies have found any measure of risk aversion to be significantly related to forward pricing use (Edelman et al., 1990; Shapiro \& Brorsen, 
1988; Makus et al., 1990; Turner et al., 1983). Goodwin and Shroeder (1994:943) report, contrary to their expectations, that "respondents with a stated preference for risk were more likely to adopt forward pricing than risk averse producers". This suggested that commercial US grain farmers viewed forward pricing as riskier than other marketing techniques. The findings of optimal hedging literature that optimal hedging ratios are less than one, implies that "forward pricing reduces income risk at low levels, but increases risk as the proportion forward priced increases" (Musser et al., 1996:66). This evidence, and the popularity of sequential and flexible marketing strategies with producers (Patrick et al., 1980; King \& Lybecker, 1983) - which implies that a combination of cash and forward pricing reduces income risk - led Musser et al. (1996) to conclude that the effect of the full range of forward pricing methods on risk reduction is unclear. A self-rating of risk aversion relative to other farmers in the region was included in an attempt to measure risk aversion in this study. The alternative risk management tools discussed below were analysed as separate explanatory variables:

- Enterprise diversification should be negatively related to the use of price risk management tools as it is a means to reduce risk, and so may be a substitute for price risk management. Diversification was measured by an index composed of the sum of the squared proportional contributions of each individual enterprise on the farm to total income. This index ranged in value from 0 (highly diversified) to 1 (completely specialised in one enterprise), so that a positive sign on this variable would indicate a risk management substitution effect.

- The proportion of total income derived from maize is expected to be positively related to sample farmers' use of price risk management tools. The more reliant the farm business is on maize for its income, the more likely it will be for any risk averse producer to use maize price risk management tools.

- Crop insurance. The use of crop insurance implies that the respondent is averse to yield risk and should thus be more likely to use price risk management tools to insure his income. Crop insurance is complementary to the use of many price risk management tools which require the physical delivery of maize.

- Maize storage facilities, either on-farm or at a cooperative/elevator company, allow producers to store crops to take advantage of seasonal price movements. Producers using these alternatives would be more exposed to price risk and thus more likely to use price risk management tools. Respondents' use of maize storage facilities, either on or off-farm, was measured by a dummy variable 


\section{( $1=$ use, $0=$ no use).}

- The proportion of farm land rented reflects arrangements that may incur fixed annual rental charges which must be met regardless of yields and prices (except for share-cropping arrangements). Producers who incur these costs may be more likely to use price risk management tools to guard against price risk which may reduce their ability to meet these fixed charges.

Marketing management rating is expected to negatively influence use of price risk management tools. Respondents who lack confidence in their own marketing skills may be more likely to utilise brokers and marketing agents. These agents and brokers may be more likely to use forward pricing tools to ensure prices prior to delivery. A self-rating of management skills relative to other farmers was included to measure the respondents' level of confidence in various areas of management.

- Producers ' perceptions of the usefulness of price risk management tools will probably affect the degree to which they adopt these tools. The following measures of producer attitudes were considered in the model as dummy variables $(1=$ agree, $0=$ otherwise):

- Expected income effects - Producers who believe their expected income will be increased by forward-pricing (1) are more likely to hedge and forward contract.

- Price stability effects - Producers who perceive that forwardpricing will stabilise prices ( 1 ) are more likely to use forward pricing tools.

- Free market preferences - Producers in favour of the freer marketing of agricultural produce (1) are expected to be more likely to use more novel marketing channels.

- Bad experiences - Farmers who have had, or know someone who has had, a bad experience (1) with a particular marketing alternative may be less likely to use that alternative.

- Off-farm income (1) may have a positive or negative effect on the use of price risk management tools. The higher the level of offfarm income, the less dependent the farmer will be on farm income. Price risk might thus not concern him as much as it would a farmer without off-farm income. Conversely, a farmer with significant off-farm income might be more acquainted with business and financial matters and be more likely to use price risk management tools.

- Time spent reading publications of an agricultural or financial nature is expected to positively influence use of price risk management tools. Producers who spend relatively more time reading these sources may be more likely to be "early-adopters" due to the additional insight and 
knowledge gained. The average number of hours spent reading agricultural and financial publications was used as the proxy for this variable.

- Communication infrastructure would directly influence the ability to use certain marketing channels. Farmers with access to reliable communications media are more able to monitor and manage price risk management tools. An inverse index of communications infrastructure was created to measure this variable. This index was created in a similar manner to the enterprise diversification index mentioned earlier.

- Market information. The importance which producers attach to market information, and how they source this information, are expected to influence their use of price risk management tools. Those who use subscription-based information sources are expected to be more concerned with price risk and more able to make informed decisions. Sample farmers' ratings of various information sources were considered in the model.

- Regional effects on the use of price risk management were considered by using two dummy variables to define the three study regions.

\section{Regression model results}

Table 1 shows the model coefficients (b's) and other statistics estimated after the elimination of variables with statistically insignificant $\mathrm{t}$ statistics. The $R^{2}$ statistic of the model was 35.7 percent, while the adjusted $R^{2}$ was 29.6 percent. This implies that 35.7 percent of the variation in the price risk management index score was accounted for by the explanatory variables included in the model. The adjusted $R^{2}$ statistic takes account of distortions in the data which can be caused by the loss of degrees of freedom accompanying the addition of more explanatory variables, and is considered more reliable than $R^{2}$ (Mirer, 1983).

\section{Goodness of fit}

The $F$ statistic of the regression model was highly significant (sig. $F=0.0001$ ) and all $t$-statistics were significant at least at the 10 percent level of probability. The adjusted $R^{2}$ statistic of 29.6 percent is relatively low, but as Gujarati (1995:211) notes, "it does not mean the model is necessarily bad". Measures of goodness of fit must be viewed in the context of previous US studies. Goodwin and Schroeder (1994) achieved a 72 percent correct classification of users in their Probit model of adoption of forward pricing methods. Shapiro and Brorsen (1988) achieved an equivalent $R^{2}$ statistic of 84 percent in their Tobit model of futures hedging adoption, whilst Makus et al. (1990) correctly predicted 71.8 
percent of cases in their Probit model. Goodness of fit, as measured by percentage correct classification, is not directly comparable to $R^{2}$ measures, and Logit models with correct classification percentages as high as 92 percent may have $R^{2}$ equivalents as low as 24.2 percent (Stockil, 1997). This model correctly classified 72 percent of "higher-level users" of price risk management tools (farmers with marketing index scores above the sample mean) and 69 percent of "lower-level users". Overall, 70 percent of cases were correctly classified. Edelman et al. (1990) achieved model $R$ statistics (analogous to $R^{2}$ in OLS) ranging from 18.9 percent to a maximum of 26.4 percent in four logistic regression models of discrete adoption of cash, forward contract, futures-hedged and options-hedged marketing alternatives for lowa grain farmers.

One reason for the low adjusted $R^{2}$ statistic in the South African study may be that there was little variation in the data since the sample was biased towards large, specialist maize farmers who face similar price situations and marketing decisions. The index may also understate the use of risk price management tools because of the major marketing role played by cooperatives to whom farmers may sell maize knowing that prices are guaranteed by the cooperative 's use of price risk management tools. The marketing of maize in South Africa has only recently been liberalised, whereas many of the price risk management tools measured in the index have been available to US farmers for over a century. This may have contributed to a large random component in the adoption of price risk management tools, due to the actions of local sample producers still experimenting with the new marketing alternatives available to them. The relatively small sample size $(n=84)$ may have further enhanced this random component. Similar low measures of goodness of fit were obtained by Makus et al. (1990) for a Tobit model of adoption of forward pricing for corn and soyabeans in a sample of large-scale Midwestem US farmers. This was attributed to "a large random component (effect) on forward pricing, or some non-economic explanation" (Makus et al., 1990:76). A referee of that study suggested that an alternative non-economic explanation may be that "some farmers use forward pricing because it makes them feel good".

Specification error may also have played a role in reducing the $R^{2}$ in the South African model. Although all those variables included in previously discussed models were considered in this model, some variables particularly relevant to South African maize marketing may have been excluded. The dominant role still being played by cooperatives (and former cooperatives now operating as public companies) in local maize marketing may be masking direct producer use of price risk management tools. The lack of a reliable explicit measure of risk aversion, and the risk-balancing behaviour that producers are expected to employ, may also have created specification error. These aspects could be considered in future research work related to this topic. 


\section{Table 1 Summary of OLS regression results}

\begin{tabular}{|c|c|c|c|c|c|}
\hline $\begin{array}{l}\text { Variable } \\
\text { name }\end{array}$ & Variable definition & b & $\mathbf{S E}(\mathbf{b})$ & $\bar{t}$ & Sig t \\
\hline STORAGE & $\begin{array}{l}\text { Respondent uses maize } \\
\text { storage facilities (1) or not }(0)\end{array}$ & 0.762 & 0.258 & 2.957 & 0.004 \\
\hline OFEMP & $\begin{array}{l}\text { Respondent has off-farm } \\
\text { employment (1) or not }(0)\end{array}$ & 1.113 & 0.379 & 2.938 & 0.005 \\
\hline INSURE & $\begin{array}{l}\text { Respondent covered by formal } \\
\text { crop insurance (1) or not }(0)\end{array}$ & 0.632 & 0.225 & 2.802 & 0.007 \\
\hline EDUCA & $\begin{array}{l}\text { Respondent's number of years } \\
\text { of formal education }\end{array}$ & 0.132 & 0.049 & 2.690 & 0.009 \\
\hline LNMAIZE & $\begin{array}{l}\text { Natural logarithm of the pro- } \\
\text { portion of annual tumover } \\
\text { arising from maize (both } \\
\text { yellow and white) }\end{array}$ & 0.778 & 0.301 & 2.585 & 0.012 \\
\hline MKTGM & $\begin{array}{l}\text { Self-rating of marketing ma- } \\
\text { nagement ability (on Lickert- } \\
\text { type scale of } 1 \text { (low)-5(high)) }\end{array}$ & -0.220 & 0.124 & -1.779 & 0.080 \\
\hline $\begin{array}{l}\text { CON- } \\
\text { STANT }\end{array}$ & & -0.457 & 1.600 & -0.285 & 0.776 \\
\hline
\end{tabular}

$\begin{array}{llll}R^{2} \text { Statistic } & 0.357 & \text { F Statistic } & 5.831 \\ \text { Adjusted } R^{2} \text { Statistic } & 0.296 & \text { Significance of F } & 0.0001 \\ \text { Standard Error } & 0.870 & & \end{array}$

\section{Variables included in the model}

Some inferences drawn from the theory outlined earlier linking the variables given in the estimated regression model in Table 1 to the use of price risk management tools are considered below.

\section{STORAGE}

STORAGE is a dummy variable indicating whether or not the respondent used maize storage facilities, either on-farm or at commercial silos. The positive regression coefficient implies that the use of some price risk management tools, such as forward contracting and sequential marketing, is complementary to storage activities. Farmers who are both physically and financially able to utilise maize storage facilities both on or off the farm, may have a longer planning horizon for maize marketing. They may be aiming to benefit from seasonal trends in the maize price associated with a one-off supply shock and 
steady spread of demand over time that characterise the South African maize market. Storing maize for any length of time exposes the maize inventory to increased price risk and is thus likely to increase the need to use price risk management tools. If the storer is aiming to benefit from anticipated positive price movements, hedging on futures markets would obviously not be appropriate since prices will be more or less "locked-in" apart from unexpected changes in the basis. However, sequential marketing strategies and options hedging may be used as they can capture potential benefits from positive price movements, and it is likely that these are the components of the index of price risk management affected by storage activities.

\section{OFEMP}

A priori expectations as to the effect of off-farm employment on farmers' use of maize marketing alternatives were unclear. On the one hand, employment off the farm provides an additional, often reliable source of income to respondents, reducing the seriousness of the effects of price risk on farmers, and reducing use of price risk management tools. On the other hand, farmers with off-farm employment may be more acquainted with business and financial matters and be more likely to use these tools. Access to such tools may also be easier for farmers with off-farm employment. Given that the sample is biased towards larger, specialist maize farms, the income provided by off-farm employment was probably small compared to the possible variation in income brought about by variations in the maize price. The second effect would thus outweigh the first, which is borne out by the positive sign on the regression coefficient.

\section{INSURE}

The positive coefficient of INSURE, a dummy variable indicating respondents* use (or otherwise) of crop insurance, was statistically significant at the 1 percent level of probability. The use of crop insurance - mainly in the form of hail insurance - could indicate risk averse behaviour with regard to income risk, which comprises both production and price risk. Respondents may then be considered more likely to use price risk management tools. Crop insurance could theoretically substitute for price risk management tools, resulting in a negative relationship between crop insurance and the use of these tools. However, the use of forward pricing tools often requires that physical delivery be ensured (to some degree) and crop insurance would then complement the use of price risk management tools.

\section{EDUCA}

Respondents' number of years of formal education (EDUCA) was positively related to use of price risk management tools. This supports a priori expectations and previous studies in the US (Goodwin \& Schroeder, 1994; Shapiro \& Brorsen, 1988; Makus et al., 1990). More educated farmers probably 
have lower transaction costs associated with the adoption of relatively complicated forward pricing strategies. The EDUCA variable may also capture respondents' age, as younger farmers would be expected to have relatively more years of formal education. Age was expected to be negatively related to respondents' use of price risk management tools and so the age component of EDUCA would enhance its positive effect on the use of price risk management tools. Younger, less experienced, more educated respondents who tend to make more use of these tools, may also tend to be less established farmers who are more susceptible to price risk and thus have more need to manage price risk. Various transformations (exponential, cubic and quadratic) of EDUCA were tested in the study as it was thought that use of price risk management tools should increase with the respondents' number of years of formal education at an increasing rate - the best fit, however, was linear.

\section{LNMAIZE}

The natural logarithm of the percentage contribution of maize to gross income, LNMAIZE, was positively related to the use of price risk management tools. Specialised maize farmers are more prone to maize price risk than farmers with a more diversified enterprise mix and would be more likely to utilise, and devote more time to, maize price risk management tools. The LNMAIZE measure may capture aspects of farm size as well; the focus of the sample is biased towards large, specialised maize farms, thus specialist maize producers in the sample regions are more likely to have larger farm sizes. Both the scaledependent benefits and fixed transaction costs associated with the use of certain price risk management tools, may be spread over a larger amount of output as the volume of maize marketed increases. The "lumpy" nature of contracts (minimum volume specifications) associated with futures and options hedging excludes farmers who market only small volumes of maize. The larger the proportional contribution of maize to gross income, the larger is the volume of maize likely to be marketed by the producer and the more likely that he will use price risk management tools. The logarithmic transformation implies that the use of maize price risk management tools increases at a decreasing rate as the maize share of gross income increases. Decreasing returns to size may be experienced by larger-volume maize producers or marketing management time may be limited for very large producers.

\section{MKTGM}

MKTGM represents respondents' self-rating of marketing management ability relative to other farmers in their district, measured on a Lickert-type scale ranging from 1 (low) to 5 (high). This variable was negatively related to $J_{i}$, and the estimated coefficient was statistically significant at the 10 percent level of probability. A priori expectations were that MKTGM would measure respondents' level of confidence in the use of price risk management tools and 
would thus be positively related to $\mathrm{J}_{\mathrm{i}}$. However, respondents who rated their marketing management skills highly were less likely to use price risk management tools. The explanation may be that those rating their marketing skills highly have less need for futures trading, as they are inherently better able to manage spot price risk via other marketing methods. In addition, such farmers may be using price risk management tools indirectly via intermediaries such as cooperatives, which may guarantee spot prices to farmers by using price risk management tools such as hedging. Respondents generally rated their skills in marketing management lowest compared to other aspects of management such as production and financial management, indicating concern about their inadequate marketing skills.

\section{Comparison of results with previous studies}

Table 2 compares the results of this study with those of previous US studies. Although the focus of and the statistical methods employed in this study differed from those of previous studies, the models share many similar variables. 
Table 2 Comparison of Results of this Study with Previous Studies

\begin{tabular}{|c|c|c|c|c|}
\hline $\begin{array}{l}\text { Parti- } \\
\text { culars }\end{array}$ & $\begin{array}{l}\text { This study } \\
(1998, n=84\end{array}$ & $\begin{array}{c}\text { Shapiro and } \\
\text { Brorsen } \\
(1988, n=41)\end{array}$ & $\begin{array}{c}\text { Goodwin and } \\
\text { Schroeder } \\
(1994, n=509)\end{array}$ & $\begin{array}{l}\text { Market et al. } \\
(1990, n=595)\end{array}$ \\
\hline Focus & $\begin{array}{l}\text { Factors influencing } \\
\text { producers' use of price } \\
\text { risk management tools }\end{array}$ & $\begin{array}{l}\text { Factors influencing } \\
\text { producers' participa- } \\
\text { tion in future markets }\end{array}$ & $\begin{array}{l}\text { Factors affecting } \\
\text { producers' adoption } \\
\text { of forward pricing } \\
\text { methods }\end{array}$ & $\begin{array}{l}\text { Factors influencing } \\
\text { producers' use of } \\
\text { futures and options } \\
\text { contracts }\end{array}$ \\
\hline $\begin{array}{l}\text { Target } \\
\text { popula- } \\
\text { tion }\end{array}$ & $\begin{array}{l}\text { SA commercial maize } \\
\text { producers }\end{array}$ & $\begin{array}{l}\text { Indiana maize and } \\
\text { soyabean producers }\end{array}$ & $\begin{array}{l}\text { Kansas corn, wheat, } \\
\text { soyabean, cattle and } \\
\text { pork producers }\end{array}$ & $\begin{array}{l}\text { Participants of a pilot } \\
\text { program covering } 22 \\
\text { US states }\end{array}$ \\
\hline $\begin{array}{l}\text { Statistical } \\
\text { methocds } \\
\text { employed }\end{array}$ & $\begin{array}{l}\text { Ordinary Least Squares } \\
\text { regression (OLS) }\end{array}$ & Tobit regression & Tobit regression & Probit regression \\
\hline
\end{tabular}


Table 2 continued

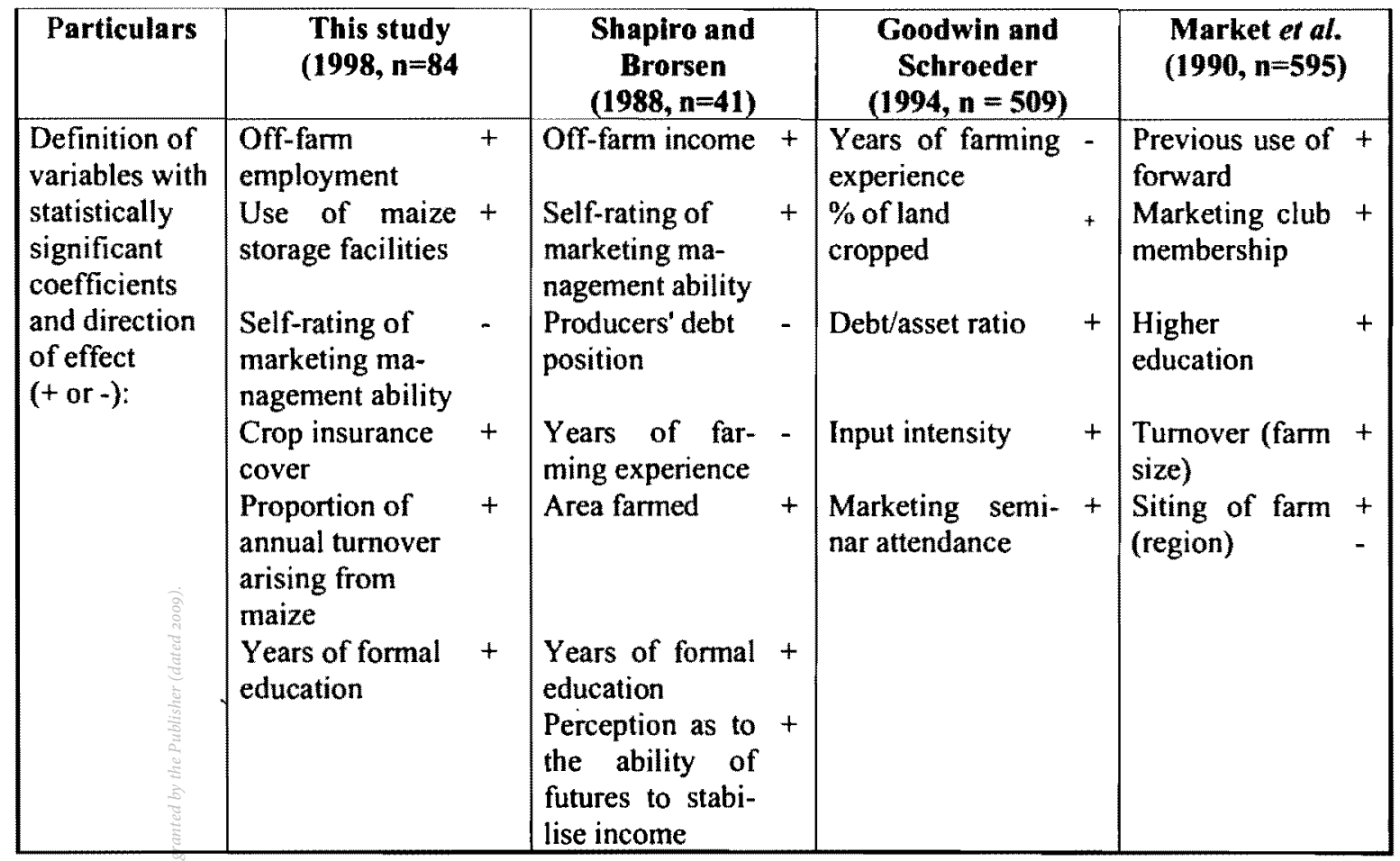


Measures of enterprise size were included in all four models. This study used the proportion of turnover arising from maize, which is related to size (correlation coefficient between proportion of turnover arising from maize and gross income $=0.277$ ). Shapiro and Brorsen (1988) used area farmed, Goodwin and Schroeder (1994) used percentage of land cropped, and Makus et al. (1990) used gross income as size measures. In all cases, size was positively related to the dependent variable.

This study and the Shapiro and Brorsen (1988) study both found that off-farm employment/income had a positive effect on farmers' use of price risk management tools/futures hedging. The two studies, however, differed in their estimation of the effect of self-rated marketing management ability on the respective dependent variables. Shapiro and Brorsen (1988) found a positive relationship and interpreted the rating as one of self-confidence in management ability. This study found a negative relationship, with the rating interpreted as an inverse measure of ability to handle price risk. These differences in the interpretation of this variable may be justified for the reason that South African maize producers have only carried full responsibility for the marketing of their crop since 1997, whilst US producers have long had access to price risk management tools.

In common with Shapiro and Brorsen (1988), this study found that use of price risk management tools/futures hedging was positively related to producers' level of education. The negative relationship between the dependent variable and years of farming experience was supported by Shapiro and Brorsen (1988) and by Makus et al. (1990). Both the education and experience variables are expected to be influenced by operators' age (all three variables were highly correlated).

The primary objective of using forward pricing methods is to reduce price risk. Previous studies reviewed did not explicitly account for risk aversion although some aspects of risk aversion are incorporated in other variables (Shapiro \& Brorsen , 1988; Goodwin \& Schroeder, 1994). One measure of risk aversion incorporated in this model was the presence or absence of formal crop insurance. It was difficult to isolate absolute price risk aversion due to the riskbalancing behaviour of producers. The INSURE measure may be considered a rather poor measure of risk aversion and future studies should carefully consider ways to objectively measure price risk aversion and account for risk-balancing effects.

Certain factors that significantly influenced adoption of various forward pricing tools in previous studies, did not significantly influence the use of price risk management tools in this model. Shapiro and Brorsen (1988) reported that 
positive perceptions of the effectiveness of hedging had a positive influence on the adoption of hedging. Goodwin and Schroeder (1994) identified marketing seminar attendance and input intensiveness as further factors positively related to use of forward pricing. Makus et al. (1990) found siting of the farm with respect to region, marketing club membership and previous use of forward contracts to further influence hedging activity in addition to farm size and operator's education. Use of maize storage facilities was the only variable in the local model that did not occur in any of the previous US models. This again emphasises the strong role still played by elevators (cooperatives and former cooperatives) in South African maize marketing.

\section{CONCLUSION}

The use of maize storage facilities, off-farm employment, use of formal crop insurance, operators' number of years of formal education and the proportion of farm turnover arising from maize all had a positive effect on sample maize farmers' use of price risk management tools. Operators self-rated score of marketing management ability was negatively related to their use of these tools.

Farmers who are able, both physically and financially, to utilise maize storage facilities are more likely to be able to use several marketing channels over time in a sequential marketing strategy. Maize storage activities incur price risk and are thus positively related to the use of price risk management tools such as hedging. Most respondents ( 70 percent) stored at least a portion of their maize (either on-farm or with elevators), implying that storage can be a profitable activity.

Off-farm employment often provides farmers with greater exposure and access to price risk management tools. Crop insurance cover implies aversion to income risk, and producers with this insurance are thus also likely to be concemed about price risk. Crop insurance is also complementary to the use of forward-pricing tools which require that the physical delivery of maize be guaranteed. Producers considering using forward-pricing tools should note that these tools may increase their exposure to yield risk if applied to too high a percentage of the crop.

Use of price risk management tools is expected to increase with operators' education since their transaction costs of adoption will be lower. More specialised maize producers may allocate a greater amount of time to, and reap greater benefits from price risk management. Opportunities for providers of price risk management services lie in the marketing education of farmers. Maize marketing seminars explaining the full range of price risk management tools 
available to maize producers would reduce the adoption costs and encourage broader producer participation. Opportunities for private sector consultants and the various institutions involved in South African maize marketing (e.g. SAFEX, NAMPO) lie in the provision of these seminars. Given the impact of farm size on adoption of price risk management tools, these seminars may have the greatest potential payoff if directed at owners of larger maize farms. The print media are already being used by various organisations to inform farmers about price risk management tools. Weekly agricultural magazines (e.g. Farmers' Weekly) were the most highly rated sources of marketing information in this study and may well be the most effective medium of producer education. Sample respondents generally rated marketing management as the weakest facet of their management - further evidence of their concern over their ability to manage price risk, and a need for producer education.

The estimated model had a low adjusted $R^{2}$ statistic, but this was comparable to some previous studies in this field. Goodness of fit as measured by percentage correct classification of cases using more price risk management than the average ( 82 percent), compared favourably with many previous studies which used Tobit and Probit models. As maize marketing in South Africa develops and matures further, more research into producers' use of price risk management tools will be needed. Future studies should carefully consider how to objectively measure price risk aversion and account for risk-balancing effects.

\section{ENDNOTE}

The authors gratefully acknowledge the guidance given by Dr Kit Le Clus of the National Maize Producers' Organisation (NAMPO) and the financial assistance provided by NAMPO and the Centre for Science Development (CSD). Opinions expressed in this paper, and conclusions arrived at, are those of the authors and are not necessarily to be attributed to NAMPO or the CSD.

\section{REFERENCES}

1 BARRY, P.J., ELLINGER, P.N., BAKER, C.B. \& HOPKIN, J.A. (1995) Financial Management in Agriculture, Fifth ed., Interstate Publishers, Inc. Danville Illinois, USA.

2 DIRECTORATE: STATISTICAL INFORMATION (1999) Abstract of Agricultural Statistics, National Department of Agriculture, Pretoria. 
3 EDELMAN, M.A., SCHMIESING, B.H. \& OLSEN, D.R. (1990) "Use of Selected Marketing Alternatives by Iowa Farmers", Agribusiness: An International Journal, 6(2): 121-32.

4 FRANK, D.B. (1992) "Agricultural Commodity Futures Markets in South Africa", Agrekon, 31(4): 313-20.

5 GOODWIN, B.K. \& SCHROEDER, T.C. (1994) "Human Capital, Producer Education Programs, and the Adoption of Forward-Pricing Methods", American Journal of Agricultural Economics, 76(4): 936-947.

6 GUJARATI, D.N. (1995) Basic Econometrics, Third ed., McGraw-Hill, New York, USA.

$7 \quad$ KING, R. \& LYBECKER, D. (1983) :Flexible, Risk-Oriented Marketing Strategies for Pinto Bean Producers", Western Journal of Agricultural Economics, 8(2): 124-33.

8 LYNE, M.C. (1998) "Personal Communication", Department of Agricultural Economics, University of Natal, Pietermaritzburg.

9 MAKUS, L.D., LIN, B.H., CARLSON, J. \& KREBIL-PRATHER, R. (1990) "Factors Influencing Farm Level Use of Futures and Options in Commodity Marketing", Agribusiness: An International Journal, 6(6): $621-30$.

10 MIELIES/MAIZE. (1997) Information as the Key to Price Determination, July 1997:5.

11 MIRER, T.W. (1983) Economic Statistics and Econometrics, First ed, MacMillan Publishing Company, New York, USA.

12 MUSSER, W.N., PATRICK, G.F. \& ECKMAN, D.T. (1996) "Risk and Grain Marketing Behavior of Large-Scale Farmers", Review of Agricultural Economics, 18(1): 65-77.

13 NORUŠIS, M. J. (1993) SPSS ${ }^{\circledR}$ for Windows: Base System User's Guide, Release 6.0, Copyright 1993 by SPSS Inc.

14 PATRICK, G.F., WHITAKER, W.N., \& BLAKE, B.F. (1980) "Farmers' Goals and Risk Aversion: Some Preliminary Analyses", Risk Analysis in Agriculture: Research and Educational Developments, Department of Agricultural Economics, University of Illinois, USA.

15 SHAPIRO, B.I. \& BRORSEN, B.W. (1988) "Factors Affecting Farmers' Hedging Decisions", North Central Journal of Agricultural Economics, 10(2): 145-53.

16 STOCKIL, R.C. (1997) "Risk and Market Deregulation: Attitudes of Commercial Farmers in KwaZulu-Natal", Unpublished MAgricMgt Thesis, Department of Agricultural Economics, University of Natal, Pietermaritzburg.

17 TURNER, S.C., EPPERSON, J.E. \& FLETCHER, S.M. (1983) "Producer Attitudes Toward Multicommodity Electronic Marketing", American Journal of Agricultural Economics, 65(4): 818-22. 
18 TURVEY, C.G. (1989) "The Relationship Between Hedging with Futures and the Financing Function of Farm Management", Canadian Journal of Agricultural Economics, 37(4): 629-38.

19 VAN DER MERWE, C. (1998) "The Contractual Commitment Between the Grain Producer and the Grain Buyer", Paper presented at the Agekon Acaderny Internet Conference on Maize Trading at http: //www.agekon.com. 